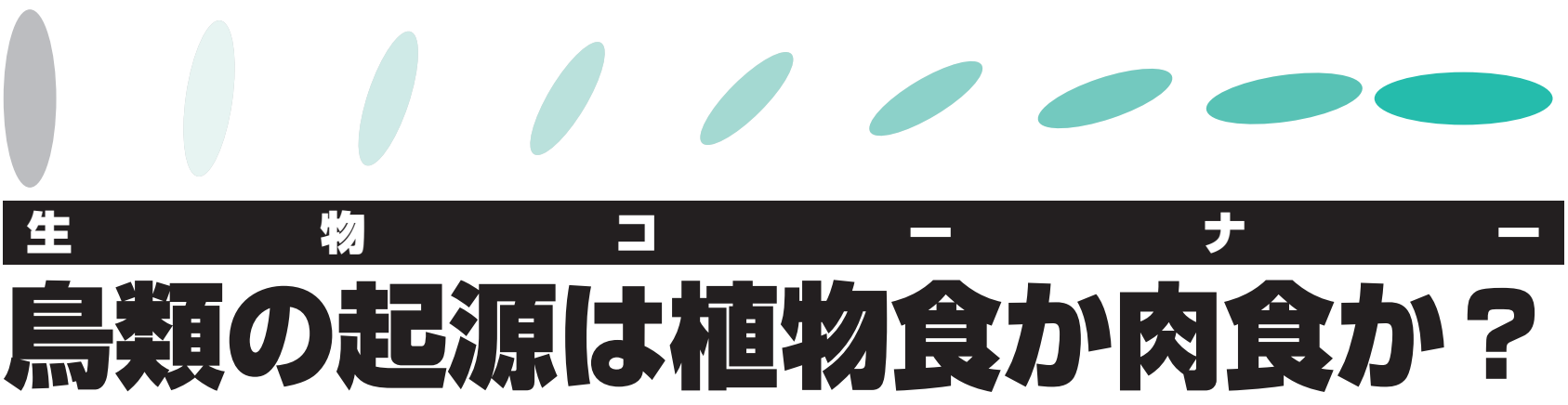

近年中国遼寧省から発見されている 多数の羽毛恐竜化石によって, 鳥類は 恐竜から進化したということが確実視 されている. しかし, 鳥類への進化過 程の解明においてはまだ課題が多く, その一つに食性の進化が挙げられる。 今回新しく発見されたテリジノサウル ス類恐竜, ジアンチャンゴサウルスに よって鳥類が植物食恐竜から進化した 可能性が高いと示唆された。 また, 植 物食への適応は, 段階を追って進化し ていったことが明らかになった．頭骨 や歯が, 先に植物食への適応をし, そ の後体の構造を進化させ, 植物食を促 進していったと考えられる。

\section{0 鳥類の起源}

始祖鳥は, 進化の象徵として知られ る化石だ。爬虫類と鳥類を結ぶミッシ ングリンクであり，鳥類が恐竜（非鳥 類型恐竜類）から進化したという証拠 の一つでもある. そして1990年代半 ばから, 羽毛の痕が残された恐竜の化 石が, 中国遼寧省から数多く発見され ている. 中国の羽毛恐竜化石が発見さ れるまでは, 始祖鳥が爬虫類と鳥類を 結ぶ唯一と言っていい化石であった が, 立て続く羽毛恐竜発見は, 鳥類の 起源が恐竜にあることを確実にし，ま た恐竜から鳥類へと進化過程が解明さ れていった.

鳥類は, 恐竜類の一グループであ る.そのため, 慣用的に「恐竜」と呼
ばれる中生代に棲んでいた動物は，正 確には鳥類を含まないため非鳥類型恐 竜と呼ぶ. 現在, 鳥類は一起源である と考えられ, 中生代の獣脚類コエルロ サウルス類から進化した。 コエルロサ ウルス類とは, 別名小型獣脚類とも呼 ばれ，体の小さい獣脚類である. 獣脚 類は, アロサウルスやティラノサウル スに代表されるように，一般的に肉食 の恐竜だ．恐竜は，中生代に地上を支 配し多様化を極めた動物であるが, 肉 食に適応したのは獣脚類恐竜だけであ る.

\section{0 食性の進化}

鳥類は，大空を自由に羽ばたいてい る. 長い生命史で, ここまで飛翔に適 応し, 多様化を成功させた春椎動物 は，鳥類だけと言ってよい。事実, 現 在の鳥類の種類は 1 万種ほど棲息し, 哺乳類の倍程度ある。約 6,600 万年前 に小天体が衝突し恐竜が大量絶滅した 後の新生代は, 哺乳類時代と呼ばれる が, それは人間のエゴである。種類の 数から言うと, 鳥類のほうが繁栄し, 現在は哺乳類時代ではなく, 鳥類時 代，いや恐竜時代であるとも言える。

ご存知のとおり, 現在の鳥類には猛 禽類のように肉食性のものから, オウ ムのように植物食（穀物食）のものま で, その食性は多彩だ. 中生代の獸脚 類から鳥類は進化した. 獣脚類は, 肉 食としてスタートしたが，鳥類に進化
するにあたって，雑食・植物食に適応 していった.

ここで問題なのは, 一体いつ肉食か ら雑食・植物食に進化したのかという ことだ。この問題は, 鳥類起源を考え るうえで非常に重要である. 雑食・植 物食の進化の夕イミングによって, 鳥 類起源の考えが 180 度変わってしまう からだ.

考えられるシナリオは2つある. （1）肉食性の恐竜から鳥類は進化し た.（2）雑食・植物食の恐竜から鳥類 は進化した(1).これらのシナリオは, (1) 生態系のトップに位置する強者 （肉食性）から鳥類が進化した，(2) 生態系のなかでも弱者（雑食・植物 食)である恐竜が逃げるように空へ逃 げていくことで鳥類は進化したと言い 換えることができる，つまり，今大成 功を収めている鳥類は, どのようにこ の世界に出現したのか, その大進化の 過程を理解するうえで, 食性の進化は 重要であることは明らかである.

\section{新しい恐竜の発見}

中国河南省にある河南省地質博物館 は，遼寧省から発見された恐竜を購入 した.この化石は, 下部白亜系義県層 (バレミアン期：約 1 億 2 千 5 百万年 前）から発見されたもので，ほほ全身 がそろっている骨格化石だった ${ }^{(2)}$ (図1). 2010 年から, 北海道大学総合博物館 河南地質博物館 - 中国科学院地質研究 


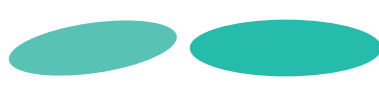

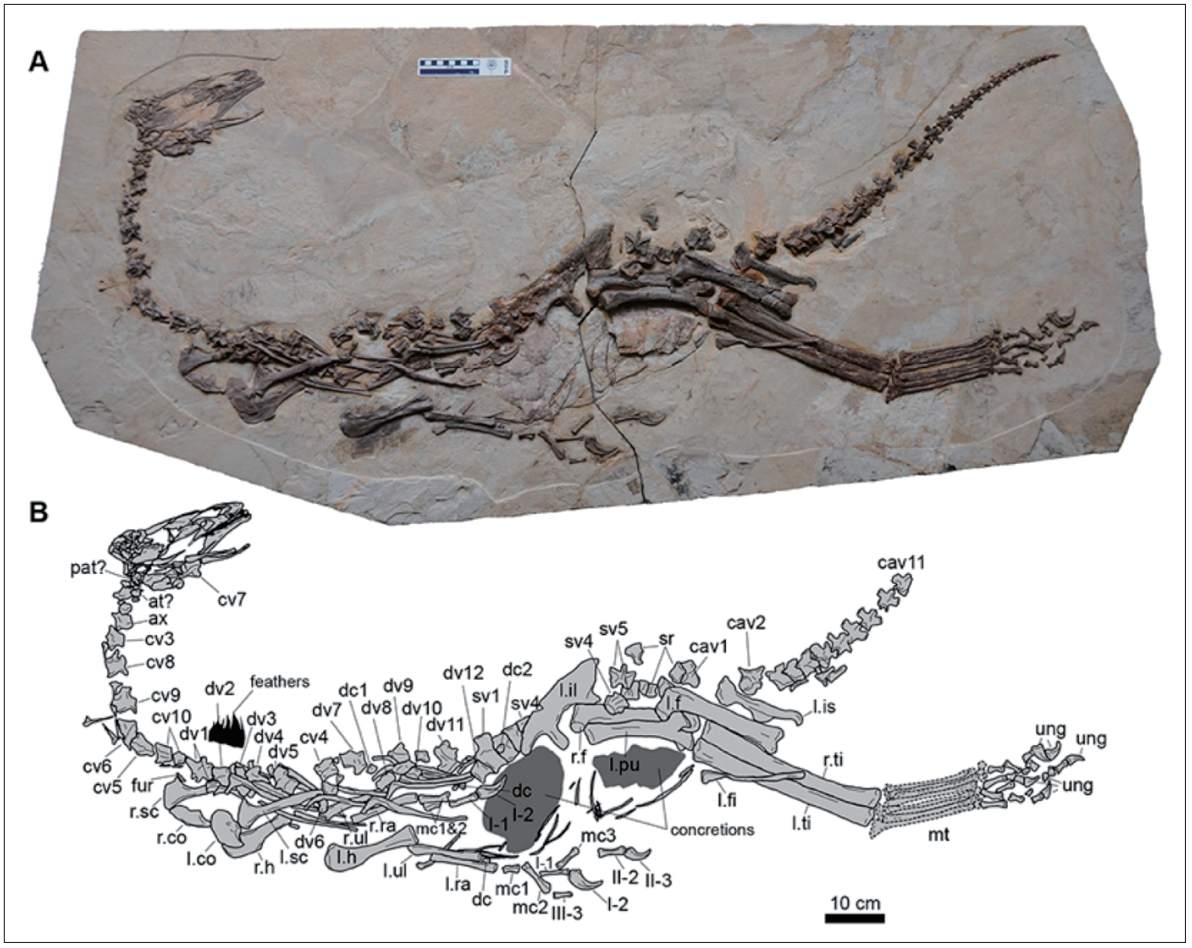

所で共同調査が始まった。その研究の 結果, この恐竜は獣脚類のテリジノサ ウルス類に属すことが判明した.

テリジノサウルス類は, 中国・モン ゴル・米国の白亜系から発見されてい る恐竜で, 特異な獣脚類恐竜として有 名である，その特異性により，以前は 竜脚類（ブラキオサウルスなど巨大な 植物食恐竜）に類似しているという考 えもあったが，近年の系統解析により 獣脚類コエルロサウルス類であること が受け入れられている. その特異性 は, モンゴルのセグノサウルス Segnosaurus に代表されるように，歯の 鋸歯が大きく，骨盤が異常に広ため体
腔が大きいことが挙げられる ${ }^{(3)}$.これ らの特徴は, テリジノサウルス類が植 物性であることが示唆する。また，テ リジノサウルス類の一種テリジノサウ ルス Therizinosaurus は大きな爪をも つことでも有名で（図2），テリジノ サウルス類は謎の多い恐竜として世の 中に知られている.

北大と中国との共同研究により，親 属新種のテリジノサウルス類恐竜であ ることが明らかになり，この恐竜をジ アンチャンゴサウルス・イシアネンシ ス Jianchangosaurus yixianensis と命 名した。
図 1 ロ ジアンチャンゴサウルスの全 身骨格化石

\section{ジアンチャンゴサウルス}

系統解析により, ジアンチャンゴサ ウルスはアジアで最も原始的なテリジ ノサウルス類であることが判明した. また，ジアンチャンゴサウルスに原始 的な羽毛（長広繊維状羽毛, Elongate broad filamentous feathers) が生え ていたことがわかった. 幅 $2 \sim 3$ ミリ と原始的な羽毛にしては幅広く，また 長さが10センチほどあったと考えら れる。

ジアンチャンゴサウルスの発見に よって, 肉食の恐竜によって構成され 


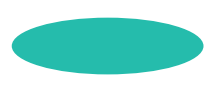

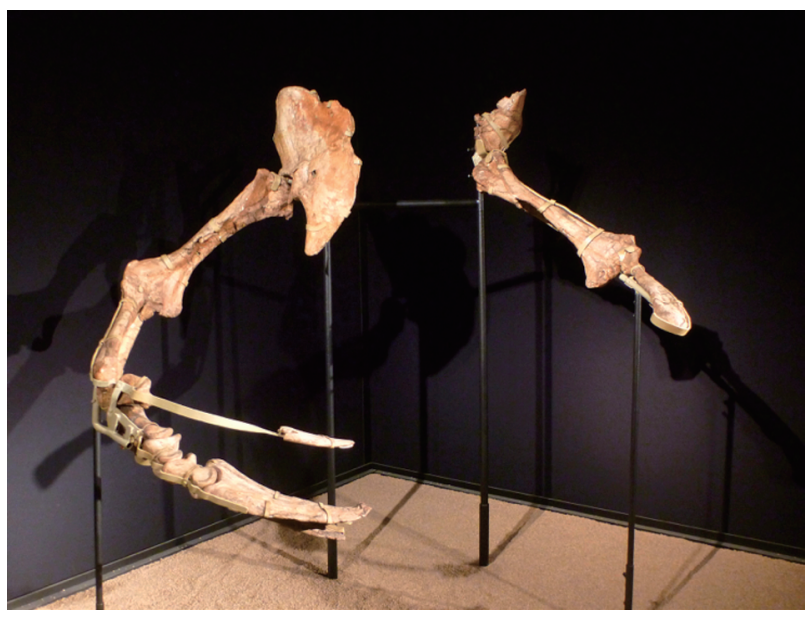

図2匹派生的なテリ ジノサウルス類であ るテリジノサウルス の腕

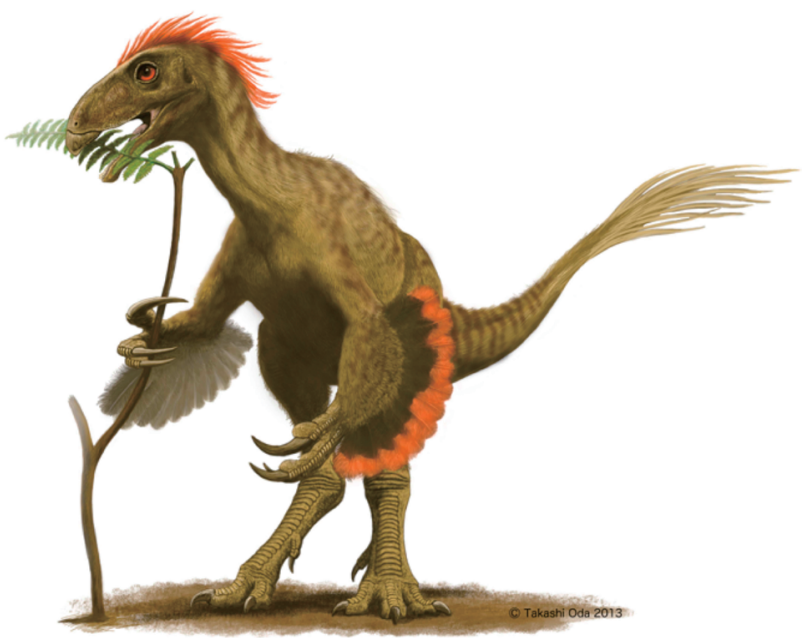

図3"ジアンチャン ゴサウルスの復元画 （小田 隆 画）

れておらず，驚きの発見であった。こ のことから， ジアンチャンゴサウルス が植物を食べていた恐竜であることが 確実視された.

ジアンチャンゴサウルスの歯や顎の 構造によって, 頭骨に植物食性の適応 が起こっていたことが明らかになった が，その一方で身体はまだ原始的でほ かの獣脚類のように走行性の高い身体 の作りをしていた。この発見によっ て, テリジノサウルス類は, 初期進化 では歯や顎の構造を進化させ，まず植 物食性へ適応をし，その後巨大化に伴 う体腔の拡大によって植物を消化した と考えられた。このように，身体の部 分によって進化の時差があることを解 明した ${ }^{(4)}$.

この進化の時差も考えれば当然のこ とで，まず口内消化を発達させること で, 食べ物の摂取が可能となる。最初 は, 少しずつ肉食から植物食へ移行し ていくが, そのうち植物食が促進さ れ, 体の構造をさらに進化させ, 多く 摂取される植物を消化していく.この ように，段階を踏むことで，食性を変

ていると思われていた獣脚類恐竜のな かで，テリジノサウルス類が植物食で あったことが確認された（図3）。 ま た，テリジノサウルス類のかなり初期 の段階で植物食の進化が起こっていた ことを明らかになった. ジアンチャン ゴサウルスの歯や顎の構造が, 恐竜の
なかで最も植物食に適応していたと考 えられている鳥脚類（ハドロサウルス やマイアサウラなど）や角竜類（トリ ケラトプスなど）の構造に似ており， 収斂進化をしていたことがわかった。 獣脚類のなかで, 植物食に適応するた めこれまでの収斂を起こした例は知ら
えていったと考えられる。

鳥類は，植物食恐竜から進化したの か?

この問いには簡単に答えられない. しかし, 今回のジアンチャンゴサウル スの発見によって，鳥類に進化する前 のコエルロサウルス類（テリジノサウ 
ルス類）にかなり植物食性に偏った進 化が見られたのは確かである。コエル ロサウルス類のなかで, 植物食として 近年提唱されているものに，オルニト ミモサウルス類, オヴィラプトロサウ ルス類やアルヴァレッツサウルス類な どが挙げられている ${ }^{(5)}$. 鳥類に進化す る前のコエルロサウルス類に，これだ け多く植物食のものが存在するのであ れば，鳥類は植物食恐竜から進化した と考えるのが妥当であろう。

しかしその一方で, 肉食恐竜のなか でもさらに肉食性に優れている，「超 肉食恐竜」のティラノサウルス類やド ロマエオサウルス科もコエルロサウル ス類に含まれる ${ }^{(6)}$. 実際, 脳の研究か
らは，肉食性のコエルロサウルス類か ら鳥類が進化したとも考えられてい る.

このように，コエルロサウルス類 は，極端に植物食に進化したものがい たかと思えば，その逆に極端に肉食性 に進化したものもいた．非常に複雑な 食性の進化野中で鳥類が出現したとも 考えられる. 非常に後味は悪いが, 恐 竜から鳥類への進化過程で，一体いつ 雑食・植物食が進化したかは，まだ議 論の最中である。まだ，決定的な結論 はでていないが非常に興味深く, 重要 な研究であることは間違いない.

\section{参考文献}

1) L. E. Zanno \& P. J. Makovicky: Proc. Natl Acad. Sci. USA, 108, 232 (2010).

2) H. Pu, Y. Kobayashi, J. Lü, L. Xu, Y. Wu, H. Chang, J. Zhang \& S. Jia: PLoS ONE, 8, e63423 (2013).

3) L. E. Zanno: Journal of Systematic Palaeontology, 8, 503 (2010).

4) Y. Kobayashi \& R. Barsbold: Canadian Journal of Earth Sciences, 42, 1501 (2005).

5) Y. Kobayashi, J. Lü, Z. Dong, R. Barsbold, Y. Azuma \& Y. Tomida : Nature, 402, 480 (1999).

6) D. K. Zelenitsky, F. Therrien \& Y. Kobayashi:Proc. R. Soc. B, 276, 667 (2009).

(小林快次, 北海道大学総合博物館)

\section{プロフィル}

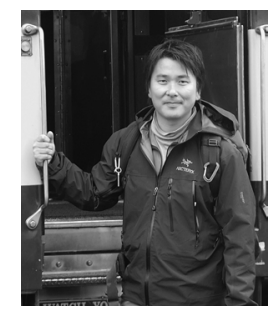

小林 快次 (Yoshitsugu KOBAYASHI)

<略歴> 2004年米国サザンメソジスト大 学地球科学科卒業 $/ 2005$ 年北海道大学総 合博物館助手 $/ 2008$ 年同助教 / 2009 年准 教授＜研究テーマと抱負 $>$ 恐竜から鳥類へ の進化過程の解明, 恐竜生態復元を研究 テーマとしている 